\title{
USE OF ESSENTIAL OILS IN ONYCHOMYCOSIS: AN INTEGRATIVE REVIEW
}

\author{
Taynnar Barbosa Ribeiro (D), Jefferson Abraão Caetano Lira'1,3 (D), Sandra Marina Gonçalves \\ Bezerra1,* (D), Rosangela Aparecida Oliveira' (D), Raylane da Silva Machado² (D), \\ Lídya Tolstenko Nogueira ${ }^{3}$ (1)
}

\begin{abstract}
Objective: identify in the literature how essential oils are used in onychomycosis. Methods: integrative review with searches performed in the MEDLINE/PubMed, Web of Science, Cochrane, SCOPUS and BVS databases, with 13 studies analyzed. Results: the use of essential oils Melaleuca alternifolia, Lavandula angustifolia, Eucalyptus citriodora and Foeniculum vulgare are effective and bring benefits in the treatment of onychomycosis, as they inhibit the mycelial growth of the nail fungus. Therefore, health professionals involved in the care of people with onychomycosis must keep themselves updated on such treatment alternatives and, consequently, on improving the care provided to these patients. Conclusion: the antifungal efficacy of a variety of oils has been proven with different forms of presentation and possible associations. However, the level of evidence presented was low, which justifies the need for more robust studies on the subject.
\end{abstract}

DESCRIPTORS: Stomatherapy. Onychomycosis. Nail diseases. Oils. Volatile.

\section{USO DOS ÓLEOS ESSENCIAIS EM ONICOMICOSE: REVISÃO INTEGRATIVA}

\section{RESUMO}

\begin{abstract}
Objetivo: identificar na literatura como os óleos essenciais são utilizados em onicomicose. Métodos: revisão integrativa com buscas realizadas nas bases de dados MEDLINE/PubMed, Web of Science, Cochrane, SCOPUS e BVS, sendo 13 estudos analisados. Resultados: o uso de óleos essenciais Melaleuca alternifólia, Lavandula angustifólia, Eucalyptus citriodora e Foeniculum vulgare mostram-se eficazes e trazem benefícios no tratamento da onicomicose, por inibirem o crescimento micelial dos fungos infectantes das unhas. Sendo assim, os profissionais de saúde envolvidos nos cuidados em pessoas com onicomicose devem se manter atualizados sobre tais alternativas de tratamento e consequentemente da melhora da assistência prestada a esses pacientes. Conclusão: a eficácia antifúngica de uma variedade de óleos foi comprovada com diferentes formas de apresentação e possíveis associações. Entretanto, o nível da evidência apresentado foi baixo, o que justifica a necessidade de estudos mais robustos sobre a temática.
\end{abstract}

DESCRITORES: Estomaterapia. Onicomicose. Doenças da unha. Óleos voláteis.

1. Universidade Estadual do Piauí - Centro de Ciencias da Saúde - Especialização em Estomaterapia - Teresina (PI), Brazil.

2. Universidade Federal do Piauí - (PI), Brazil.

3. Universidade Federal do Piauí - Departamento de Enfermagem - Programa de Pós- Graduação em Enfermagem - Teresina (PI), Brazil.

*Correspondence author: sandramarina@ccs.uespi.br

Section Editor: Juliano Teixeira Moraes

Received: Jan. 13, 2021 | Accepted: Abr. 19, 2021

How to cite: Ribeiro TB; Lira JAC; Oliveira RA; Bezerra SMG; Machado RS; Nogueira LT. Use of essential oils in onychomycosis: an integrative review. ESTIMA, Braz. J. Enterostomal Ther., 2021, 19: e1321. https://doi.org/10.30886/estima.v19.1011_IN 


\title{
USO DE ACEITES ESENCIALES EN ONICOMICOSIS: REVISIÓN INTEGRATIVA
}

\begin{abstract}
RESUMEN
Objetivo: Identificar en la literatura cómo se utilizan los aceites esenciales en la onicomicosis. Métodos: Revisión integrativa, con búsquedas realizadas en las bases de datos MEDLINE / PubMed Web of Science, Cochrane, SCOPUS y VHL, donde se analizaron 13 estudios. Resultados: El uso de los aceites esenciales Melaleuca alternifolia, Lavandula angustifolia, Eucalyptus citriodora y Foeniculum vulgare resulta eficaz y aporta beneficios en el tratamiento de la onicomicosis ya que inhiben el crecimiento micelial del hongo ungueal. Así, los profesionales sanitarios implicados en la atención de las personas con onicomicosis onicomicosis deben mantenerse actualizados sobre dichas alternativas de tratamiento y, en consecuencia, sobre la mejora de la atención que se brinda a estos pacientes. Conclusión: La eficacia antifúngica de una variedad de aceites ha sido probada con diferentes formas de presentación y posibles asociaciones. Sin embargo, el nivel de evidencia presentado fue bajo, lo que justifica la necesidad de estudios más robustos sobre el tema.
\end{abstract}

DESCRIPTORES: Estomaterapia Onicomicosis. Enfermedades de la uña. Aceites Volátiles. Aceites esenciales.

\section{INTRODUCTION}

Onychomycosis is a fungal infection that occurs on the nails and can affect the adjacent skin. It affects the nails of the feet more frequently than the nails of the hands and is characterized by discoloration of the nail, thickening of the nail plate and onycholysis. It is the most common nail pathology and represents about $90 \%$ of nail infections worldwide ${ }^{1}$.

The prevalence of the disease increases with a variety of risk factors, such as old age, abnormal nail morphology, immunodeficiency and genetic factors. Onychomycosis is a substantial health problem as it can have negative health consequences, such as pain, discomfort and physical impairment ${ }^{2}$.

National and international studies have found dermatophytes as the most commonly found etiologic agents in onychomycosis, being represented by the genera Trichophyton, Microsporum and Epidermophyton, followed by yeasts, represented mostly by the genus Candida, as well as by non-dermatophyte filamentous fungi, in which the Scopulariopsis, Fusarium and Aspergillus are the main genera ${ }^{3-5}$.

In more developed countries, the use of closed shoes, characteristic of large urban centers, creates an environment prone to onychomycosis by filamentous fungi. The humidity and the high temperature inside the shoes are conditions that favor the development of dermatophytes. On the other hand, walking barefoot in contact with the soil and vegetation is a habit that would favor onychomycosis by non-dermatophyte fungi (NDF) ${ }^{6,7}$. In view of the presentation of the pathology and its complexity, the use of essential oils in patients with onychomycosis is highlighted, in order to act in a beneficial way in its control.

Essential oils are highly perfumed and volatile organic compounds obtained by extracting various parts of plants. It usually has a watery and clear consistency, but can be solid at lower temperatures. They are soluble in alcohol, ether and other fatty compounds; insoluble in water and may have no color or present from light tones to darker and opaque. Brazil occupies a recognized position in the production of essential oils, alongside India, China and Indonesia, which are on the list of the four largest world producers ${ }^{8}$.

Essential oils are called volatiles, because when they are in contact with air, at room temperature, they evaporate. Sparkling or ethereal are other names that can be found. However, the most used term is essential oil, as these represent the "essences" or odorous compounds of plants9. Terpenes, esters, ethers, alcohols, phenols, aldehydes, oxides, ketones, organic acids and other components detected as trace elements are the main constituents ${ }^{10}$. 
When talking about the physiological an/or pharmacological action of essential oils, the effect is similar to that of a medicine or cosmetic, that is, according to the chemical substances found in the oil. These actions may be: analgesic, antibiotic, anti-inflammatory, antiseptic, antitoxic, astringent, bactericidal, depurative, diuretic, disinfectant, solvent, stimulant, among others ${ }^{11}$.

Thus, the realization of this study on the use of essential oils in onychomycosis aims to seek relevant data on the theme that has not yet been studied, thus showing the importance of the development of clinical research that serves as a subsidy for prevention and for the use of the multidisciplinary team with emphasis in specialized care by stomatherapy. Essential oils are considered materials that are easy to apply and access, characteristics that can provide differentiated care in the face of the needs of this public. In this context, this review aims to identify in the literature how essential oils are used in onychomycosis.

\section{METHOD}

Integrative literature review, guided in six phases: definition of the research question, sampling or search in the literature, extraction of data from included studies, evaluation of productions, interpretation of results and synthesis of knowledge or presentation of the review12. To elaborate the guiding question, the PICo strategy was used, defining: $\mathrm{P}=$ population: "original studies", I = interest: "essential oils" and Co = context: "onychomycosis". Therefore, the question in this study was: how are essential oils used in onychomycosis?

Primary source studies, without temporary delimitation, that dealt with the use of essential oils in the treatment of onychomycosis were included. Exclusion criteria were defined as studies published only as abstracts, theses, dissertations and editorials. The search took place between the months of July and August 2019, by consulting the following databases: MEDLINE/PubMed (Medical Literature Analysis and Retrieval System Online), Cochrane, Web of Science, SCOPUS and BVS (Biblioteca Virtual em Saúde). It should be noted that articles duplicated in more than one database were counted only once.

The descriptors were selected by consulting the terms of the Health Sciences Descriptors (Descritores em Ciências da Saúde-DeCS) for BVS database and Medical Subject Headings (MeSH) for the other databases. Observing the peculiarities and distinct characteristics of each database, systematic strategies were built using the advanced search. The controlled and non controlled descriptors, within each set of terms in the PICo strategy, were combined with the Boolean operator OR and then crossed with the Boolean operator AND, as shown in Table 1.

Initially, 58 productions were found, of which 20 were removed from the study due to duplication. After analyzing the titles and abstracts, 11 were excluded because they were not primary articles and 4 presented only the abstract available in the database. The reading of the full text to assess eligibility excluded 11 other articles for not answering the research question, and the final sample consisted of 13 articles. Fig. 1 describes the path taken for the identification, inclusion and exclusion of studies, according to the consulted base.

Data extraction was performed with the aid of a specific instrument, containing the following information: main author, year of publication, title, place and type of study, objective, intervention, main results and level of evidence (LE). For the LE analysis, the concepts proposed by Melnyk and Fineout-Overholt were adopted13:level I - evidence from systematic review or meta-analysis of all relevant randomized controlled clinical trials or from clinical guidelines based on systematic reviews of randomized controlled clinical trials; level II - evidence derived from at least one well-designed randomized controlled clinical trial; level III - evidence obtained from well-designed clinical trials without randomization; level IV - evidence from well-designed cohort and case-control studies; level V - evidence from systematic review of descriptive and qualitative studies; level VI - evidence derived from a single descriptive or qualitative study; and level VII - evidence from the opinion of authorities and/or reports from expert committees. 
Table 1. Controlled, non-controlled descriptors and search expressions used to retrieve articles. Teresina (PI) - 2019.

\begin{tabular}{|c|c|c|}
\hline \multicolumn{3}{|r|}{ MeSH } \\
\hline \multirow{2}{*}{$\mathbf{P}$} & DC & - \\
\hline & DNC & - \\
\hline \multirow{2}{*}{ I } & DC & "Oils, Volatile", Melaleuca, Clove Oil, Thymus Plant \\
\hline & DNC & Oils, Volatile, Volatile Oils, "Oils, Essential”, Essential Oils, Melaleuca, Clove Oil, Thymus Plant \\
\hline \multirow{2}{*}{$\mathrm{CO}$} & DC & Nail Diseases, Onychomycosis \\
\hline & DNC & Nail Diseases, Nail Disease, Onychomycosis, Onychomycoses, Nail Fungus, Tinea Unguium \\
\hline \multirow{4}{*}{ 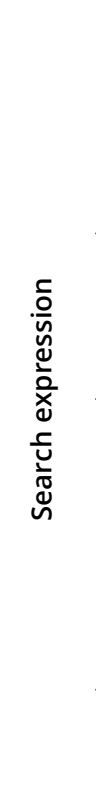 } & SCOPUS & $\begin{array}{l}\text { ( ( TITLE-ABS-KEY ( "Oils, volatile" ) OR TITLE-ABS-KEY ( "volatile oils" ) OR TITLE-ABS-KEY ( "essential } \\
\text { oils" ) OR TITLE-ABS-KEY ( melaleuca) OR TITLE-ABS-KEY ( "clove oil") OR TITLE-ABS-KEY ( "thymus } \\
\text { plant" )) ) AND ( ( TITLE-ABS-KEY ( "nail diseases") OR TITLE-ABS-KEY ( "nail disease" ) OR TITLE-ABS- } \\
\text { KEY ( onychomycosis ) OR TITLE-ABS-KEY ( onychomycoses ) OR TITLE-ABS-KEY ( "nail fungus" ) OR } \\
\text { TITLE-ABS-KEY ("tinea unguium" )) ) }\end{array}$ \\
\hline & WEB OF SCIENCE & $\begin{array}{l}\text { (TS=("oils, volatile") OR TS=("volatile oils") OR TS=("essential oils") OR TS=(melaleuca) OR TS=("clove oil") } \\
\text { OR TS=("thymus plant")) AND (TS=("nail diseases") OR TS=("nail disease") OR TS=(onychomycosis) OR } \\
\text { TS=(onychomycoses) OR TS=("nail fungus") OR TS=("tinea unguium")) }\end{array}$ \\
\hline & $\begin{array}{l}\text { MEDLINE/ } \\
\text { PUBMED }\end{array}$ & $\begin{array}{l}\text { (((((((((("oils, volatile"[MeSH Terms]) OR ("oils, volatile")) OR ("volatile oils"[All Fields])) OR ("essential } \\
\text { oils"[All Fields])) OR ("melaleuca"[MeSH Terms])) OR ("melaleuca"[All Fields])) OR ("clove oil"[MeSH } \\
\text { Terms])) OR ("clove oil"[All Fields])) OR ("thymus plant"[MeSH Terms])) OR ("thymus plant"[All Fields])) } \\
\text { AND (((((((("nail diseases"[MeSH Terms]) OR ("nail diseases"[All Fields])) OR ("nail disease"[All Fields])) } \\
\text { OR ("onychomycosis"[MeSH Terms])) OR ("onychomycosis"[All Fields])) OR ("onychomycoses"[All } \\
\text { Fields])) OR ("nail fungus"[All Fields])) OR ("tinea unguium"[All Fields])) }\end{array}$ \\
\hline & COCRHANE & $\begin{array}{l}\text { (("oils, volatile") OR ("essential oils") OR (Melaleuca) OR ("clove oil") OR ("thymus plant")) AND (("nail } \\
\text { diseases") OR ("nail disease") OR (onychomycosis) OR (onychomycoses) OR ("nail fungus")) }\end{array}$ \\
\hline \multicolumn{3}{|r|}{ DeCS } \\
\hline \multirow{2}{*}{$\mathbf{P}$} & DC & - \\
\hline & DNC & - \\
\hline \multirow[b]{2}{*}{$\mathrm{I}$} & DC & Melaleuca, Óleo de Melaleuca, Óleo de Cravo, Thymus (Planta) \\
\hline & DNC & $\begin{array}{l}\text { Óleos Essenciais, Melaleuca, Óleo de Melaleuca, Óleo de Cravo, Thymus (Planta) Thymus vulgaris, } \\
\text { Tomilho }\end{array}$ \\
\hline \multirow{2}{*}{$\mathrm{CO}$} & DC & Doenças da Unha, Onicomicose \\
\hline & DNC & Doenças da Unha, Onicopatias, Onicomicose, Fungo de Unha, Micose Ungueal, Micose de Unha \\
\hline 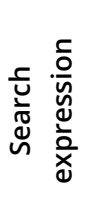 & BVS & $\begin{array}{l}\text { (("Óleos Essenciais") OR (mh:(Melaleuca)) OR (Melaleuca) OR (mh:("Óleo de Melaleuca")) OR ("Óleo de } \\
\text { Melaleuca") OR (mh:("Óleo de Cravo")) OR ("Óleo de Cravo") OR (mh:("Thymus (Planta)")) OR ("Thymus } \\
\text { (Planta)") OR ("Thymus vulgaris") OR (Tomilho)) AND ((mh:("Doenças da Unha")) OR ("Doenças da } \\
\text { Unha") OR (Onicopatias) OR (mh:(Onicomicose)) OR (Onicomicose) OR ("Fungo de Unha") OR ("Micose } \\
\text { Ungueal") OR ("Micose de Unha")) }\end{array}$ \\
\hline
\end{tabular}

$\mathrm{CD}=$ controlled descriptor; $\mathrm{NCD}=$ non controlled descriptor . 


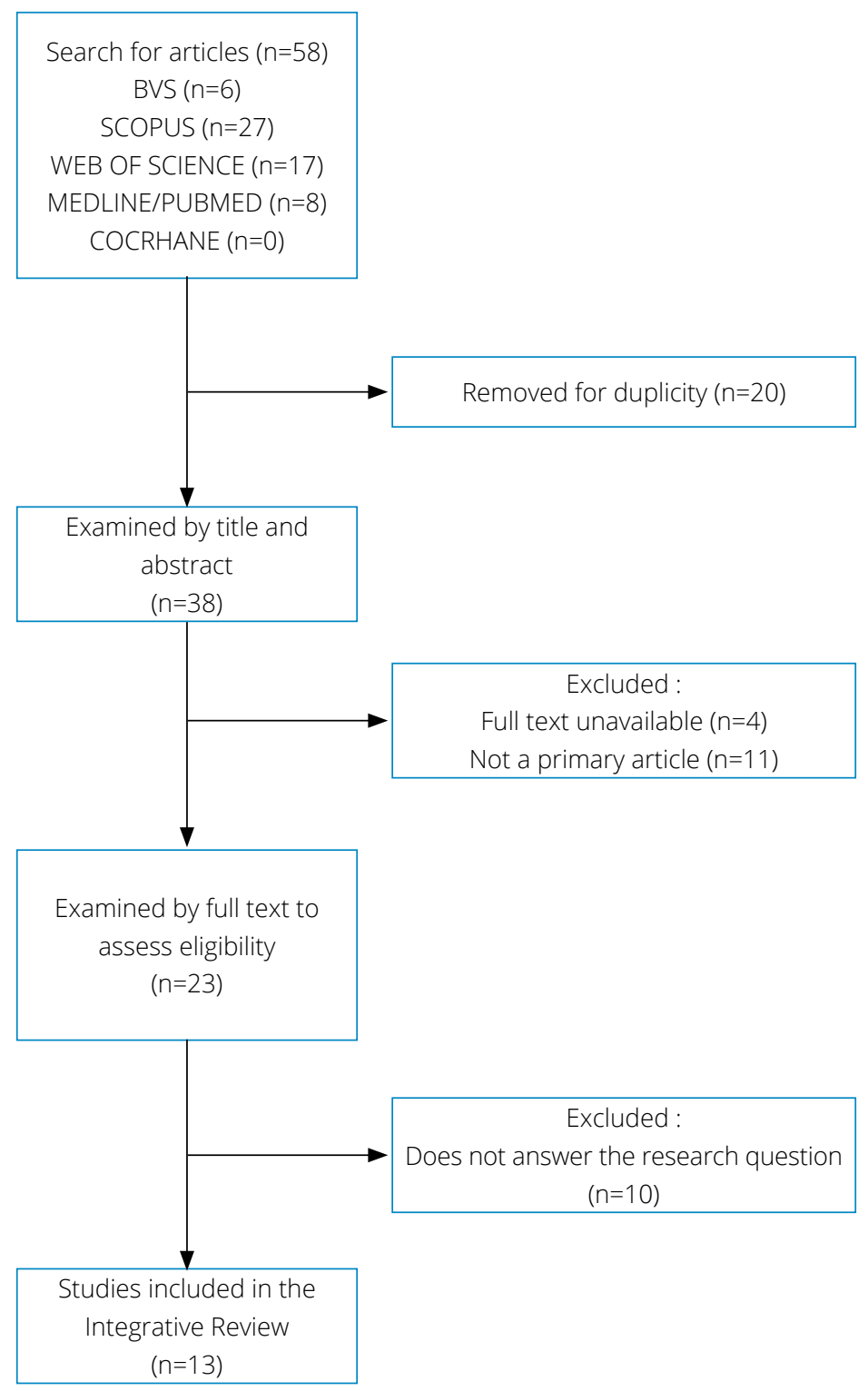

Figure 1. Retrieving and selecting studies's paths in the investigated databases. Teresina (PI) - 2019.

\section{RESULTS}

The results are shown in Table 2, according to the main author: year of publication, title, place and type of study, objective, intervention, main results and LE.

The year with the largest number of published articles was 2002 with 3 studies, followed by 2015 with 2 and the remaining years with 1 study only. It is noteworthy that the oldest study that works with the theme dates from 1994 and the most recent from 2016.

As for the language, the 13 articles were published in English. It is noteworthy that the most recent works were developed in Brazil, which also stood out in terms of location, being represented by 5 surveys, followed by the United States of America with 3 studies. Regarding LE, 11 studies are classified IV and 2 with LE II.

Melaleuca oil was highlighted over the other oils studied, as it is present in six articles. The studies presented data on efficacy, association, comparison, form of presentation and formulation. 
Table 2. Summary of review articles. Teresina (PI) - 2019.

\begin{tabular}{|c|c|c|c|c|c|c|c|}
\hline ญ & 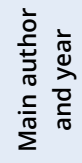 & Study title & $\begin{array}{c}\text { Study } \\
\text { location }\end{array}$ & $\begin{array}{c}\text { Type of study } \\
\text { and LE }\end{array}$ & Objective & $\begin{array}{l}\text { Intervention } \\
\text { (Essential oil) }\end{array}$ & Main results \\
\hline 飞 & 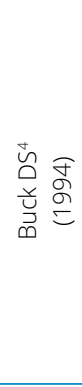 & $\begin{array}{l}\text { Comparison } \\
\text { of two topical } \\
\text { preparations for } \\
\text { the treatment of } \\
\text { onychomycosis: } \\
\text { Melaleuca } \\
\text { alternifolia } \\
\text { (tea tree) and } \\
\text { clotrimazole. }\end{array}$ & $\begin{array}{l}\text { New } \\
\text { York,USA. }\end{array}$ & $\begin{array}{l}\text { Randomized } \\
\text { controlled } \\
\text { clinical trial; } \\
\text { LE II }\end{array}$ & $\begin{array}{l}\text { To evaluate the } \\
\text { efficacy and } \\
\text { tolerability of } \\
\text { topical application } \\
\text { of } 1 \% \text { clotrimazole } \\
\text { solution compared } \\
\text { to } 100 \% \text { Melaleuca } \\
\text { alternifolia } \\
\text { (tea tree) oil for } \\
\text { the treatment of } \\
\text { onychomycosis. }\end{array}$ & $\begin{array}{l}\text { Melaleuca } \\
\text { alternifolia }\end{array}$ & $\begin{array}{l}\text { All current therapies have high rates of } \\
\text { recurrence. Oral therapy has the additional } \\
\text { disadvantages of high cost and potentially } \\
\text { serious adverse effects. Topical therapy, } \\
\text { including the two preparations presented } \\
\text { in the study, improves the symptoms } \\
\text { and appearance of the nails. The use of } \\
\text { a topical preparation in conjunction with } \\
\text { debridement is an appropriate initial } \\
\text { treatment strategy. }\end{array}$ \\
\hline$\underset{\leftarrow}{\gtrless}$ & 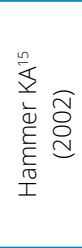 & $\begin{array}{l}\text { Melaleuca } \\
\text { alternifolia (tea } \\
\text { tree) oil inhibits } \\
\text { the formation } \\
\text { of germ tube by } \\
\text { Candida albicans. }\end{array}$ & $\begin{array}{l}\text { Nedlands, } \\
\text { Australia. }\end{array}$ & $\begin{array}{l}\text { Cohort study; } \\
\text { LE IV }\end{array}$ & $\begin{array}{l}\text { Investigate the } \\
\text { effects of Melaleuca } \\
\text { oil on the formation } \\
\text { of germ tubes by } \\
\text { Cândida albicans. }\end{array}$ & $\begin{array}{l}\text { Melaleuca } \\
\text { alternifolia }\end{array}$ & $\begin{array}{l}\text { Comparison of susceptibility to TTO of } \\
\text { conidia of Aspergillus niger germinated } \\
\text { and non-germinated showed that } \\
\text { germinated conidia are more susceptible } \\
\text { than non-germinated conidia. These } \\
\text { data demonstrate that tea tree oil has an } \\
\text { inhibitory and fungicidal activity. }\end{array}$ \\
\hline$\underset{\alpha}{m}$ & 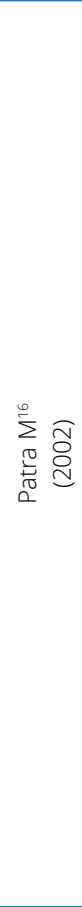 & $\begin{array}{l}\text { Use of essential } \\
\text { oil as a natural } \\
\text { antifungal against } \\
\text { infectious nail } \\
\text { fungus. }\end{array}$ & $\begin{array}{l}\text { Allahabad, } \\
\text { India. }\end{array}$ & $\begin{array}{l}\text { Cohort study; } \\
\text { LE IV }\end{array}$ & $\begin{array}{l}\text { Explore other plant } \\
\text { products (essential } \\
\text { oils) that can be } \\
\text { exploited as effective } \\
\text { fungicides. }\end{array}$ & $\begin{array}{l}\text { Foeniculum } \\
\text { vulgare }\end{array}$ & $\begin{array}{l}\text { During the antifungal screening of some } \\
\text { essential oils, Foeniculum vulgare showed } \\
\text { the strongest activity, completely inhibiting } \\
\text { the mycelial growth of infectious nail fungi, } \\
\text { Trichophyton rubrum, T. mentagrophytes } \\
\text { and Scytalidium dimidiatum. The } \\
\text { essential oil was found as a fungicide in } \\
\text { concentrations of } 0.2,0.4 \text { and } 0.5 \text { Hl/ml. } \\
\text { The oil was efficiently active against } \\
\text { heavy doses of inoculum at minimal } \\
\text { concentrations of fungicides. The fungicidal } \\
\text { activity of the oil was found } \\
\text { to be thermostable up to } 80{ }^{\circ} \text { C, with no } \\
\text { decrease in the decodable activity after } \\
48 \text { months of storage. The oil also had a } \\
\text { broad fungitoxic spectrum, inhibiting the } \\
\text { mycelial growth of other infectious fungi } \\
\text { on the nails, such as Aspergillus flavus, } \\
\text { A. fumigatus, A. niger, A. ustus, Candida } \\
\text { albicans, Epidermophyton floccosum, } \\
\text { Microporum audouinii, M. canis, M. gypseum, } \\
\text { M. nanum, Rhizopus nigricans, Trichophyton } \\
\text { tonsurans and T. violaceum. Furthermore, } \\
\text { it did not show any adverse effects on the } \\
\text { skin and nails of mammals up to } \\
5 \% \text { concentration. }\end{array}$ \\
\hline 安 & 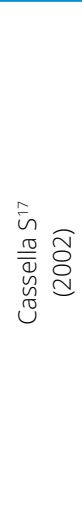 & $\begin{array}{l}\text { Synergistic } \\
\text { antifungal activity } \\
\text { of essential } \\
\text { oils of tea tree } \\
\text { (Melaleuca } \\
\text { alternifolia) } \\
\text { and lavender } \\
\text { (Lavandula } \\
\text { angustifolia) } \\
\text { against } \\
\text { dermatophyte } \\
\text { infection. }\end{array}$ & $\begin{array}{l}\text { Derby, United } \\
\text { Kingdom. }\end{array}$ & $\begin{array}{l}\text { Cohort study } \\
\text { LE IV }\end{array}$ & $\begin{array}{l}\text { The antifungal } \\
\text { potential of the } \\
\text { essential oils of } \\
\text { Melaleuca and } \\
\text { Lavender, alone } \\
\text { and in combination, } \\
\text { against common } \\
\text { causes of tinea } \\
\text { infection in } \\
\text { humans, has been } \\
\text { investigated through } \\
\text { in vitro investigations, } \\
\text { in order to determine } \\
\text { a suitable dosage for } \\
\text { use in clinical trials. }\end{array}$ & $\begin{array}{l}\text { Melaleuca } \\
\text { alternifólia } \\
\text { and Lavandula } \\
\text { angustifolia }\end{array}$ & $\begin{array}{l}\text { The results confirm that the synergistic } \\
\text { action occurs between these two essential } \\
\text { oils commonly used to effect antifungal } \\
\text { activity. }\end{array}$ \\
\hline
\end{tabular}


Table 2. Continuation...

\begin{tabular}{|c|c|c|c|c|c|c|c|}
\hline$\frac{0}{0}$ & 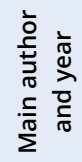 & Study title & $\begin{array}{c}\text { Study } \\
\text { location }\end{array}$ & $\begin{array}{c}\text { Type of study } \\
\text { and LE }\end{array}$ & Objective & $\begin{array}{l}\text { Intervention } \\
\text { (Essential oil) }\end{array}$ & Main results \\
\hline$\stackrel{\llcorner}{\varangle}$ & 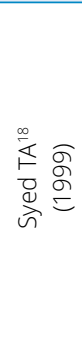 & $\begin{array}{l}\text { Treatment of } \\
\text { onychomycosis } \\
\text { with } 2 \% \\
\text { butenafine and } \\
5 \% \text { Melaleuca } \\
\text { alternifolia oil (tea } \\
\text { tree) in cream. }\end{array}$ & $\begin{array}{l}\text { San Francisco, } \\
\text { United States. }\end{array}$ & $\begin{array}{l}\text { Randomized } \\
\text { controlled } \\
\text { study; } \\
\text { LE II }\end{array}$ & $\begin{array}{l}\text { To evaluate the } \\
\text { clinical efficacy } \\
\text { and tolerability } \\
\text { of } 2 \% \text { butenafine } \\
\text { hydrochloride } \\
\text { and } 5 \% \text { Melaleuca } \\
\text { alternifolia oil in } \\
\text { cream to cure } \\
\text { onychomycosis in the } \\
\text { toenail. }\end{array}$ & $\begin{array}{l}\text { Melaleuca } \\
\text { alternifolia }\end{array}$ & $\begin{array}{l}\text { Topical therapy with } 2 \% \text { butenafine } \\
\text { hydrochloride and 5\% Melaleuca alternifolia } \\
\text { oil incorporated in the cream, together } \\
\text { with debridement with nail clippers is } \\
\text { safe, tolerable and significantly more } \\
\text { effective than placebo for curing toenails } \\
\text { onychomycosis. }\end{array}$ \\
\hline$\stackrel{0}{<}$ & 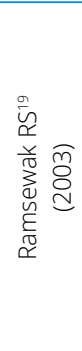 & $\begin{array}{l}\text { In vitro } \\
\text { antagonistic } \\
\text { activity of } \\
\text { monoterpenes } \\
\text { and their } \\
\text { mixtures against } \\
\text { pathogenic } \\
\text { agents of the } \\
\text { "toenail fungus". }\end{array}$ & $\begin{array}{l}\text { Michigan, } \\
\text { United States. }\end{array}$ & $\begin{array}{l}\text { Cohort study } \\
\text { LE IV }\end{array}$ & $\begin{array}{l}\text { Determine the } \\
\text { effectiveness of } \\
\text { Vick's Vaporubs } \\
\text { and the minimum } \\
\text { concentration for } \\
100 \% \text { inhibition } \\
\text { (MIC100) on } \\
\text { the pathogens } \\
\text { responsible for } \\
\text { onychomycosis. }\end{array}$ & $\begin{array}{l}\text { Eucalyptus } \\
\text { citriodora }\end{array}$ & $\begin{array}{l}\text { Formulations consisting of } 5 \mathrm{mg} / \mathrm{mL} \\
\text { camphor concentrations, menthol, thymol } \\
\text { and E. citriodora oil have the potential } \\
\text { to control onychomycosis. The main } \\
\text { components of the essential oil of E. } \\
\text { citriodora are monoterpenes such as a- } \\
\text { and } \beta \text {-pinene, cadinene, the feelandrines, } \\
\text { limonene and other known monoterpene } \\
\text { alcohols and their carbonyl analogues. }\end{array}$ \\
\hline ¿ & 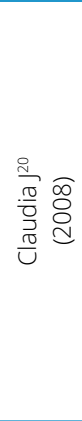 & $\begin{array}{l}\text { In vitro study of } \\
\text { the anti-Candida } \\
\text { activity of the } \\
\text { essential oil } \\
\text { of Melaleuca } \\
\text { alternifolia (tea } \\
\text { tree) associated } \\
\text { with chitosan. }\end{array}$ & Sassari, Italy & $\begin{array}{l}\text { Cohort study; } \\
\text { LE IV }\end{array}$ & $\begin{array}{l}\text { To evaluate the in } \\
\text { vitro inhibition of the } \\
\text { effect of Melaleuca } \\
\text { and chitosan oils } \\
\text { against a strain of } \\
\text { Candida albicans, } \\
\text { and to verify if the } \\
\text { anti-candida effect } \\
\text { of Melaleuca oil can } \\
\text { be reinforced by the } \\
\text { presence of chitosan. }\end{array}$ & $\begin{array}{l}\text { Melaleuca } \\
\text { alternifolia }\end{array}$ & $\begin{array}{l}\text { The in vitro activities of the commercial } \\
\text { Melaleuca alternifolia essential oil, also } \\
\text { called TTO, and chitosan were investigated } \\
\text { against Candida albicans, both alone and } \\
\text { in combination, to assess the potential of } \\
\text { their synergistic action. The anti-Candida } \\
\text { properties were evaluated using standard } \\
\text { microbiological techniques, such as the } \\
\text { MIC evaluation and the "time-kill" } \\
\text { test. The results showed that both TTO } \\
\text { and chitosan have remarkable activity } \\
\text { against Candida. }\end{array}$ \\
\hline$\stackrel{\infty}{\varangle}$ & 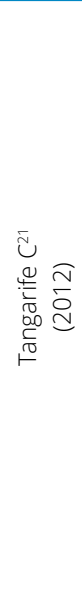 & $\begin{array}{l}\text { Antifungal activity } \\
\text { of essential oils } \\
\text { from the families } \\
\text { Verbenaceae and } \\
\text { Labiatae. }\end{array}$ & $\begin{array}{l}\text { Medellín, } \\
\text { Colombia. }\end{array}$ & $\begin{array}{l}\text { Cohort study; } \\
\text { LE IV }\end{array}$ & $\begin{array}{l}\text { To evaluate the in } \\
\text { vitro activity against } \\
\text { Trichophyton rubrum } \\
\text { dermatophytes } \\
\text { and T. } \\
\text { mentagrophytes and } \\
\text { the filamentous } \\
\text { fungus } \\
\text { Fusarium oxysporum } \\
\text { as well as the } \\
\text { cytotoxic effect } \\
\text { of essential oils } \\
\text { and extracts from } \\
\text { Colombian plants } \\
\text { belonging to the } \\
\text { Verbenaceae and } \\
\text { Labiatae families. }\end{array}$ & $\begin{array}{l}\text { Essential oils } \\
\text { and extracts } \\
\text { from families } \\
\text { Verbenaceae } \\
\text { and Labiatae }\end{array}$ & $\begin{array}{l}\text { The results confirm the antimycotic } \\
\text { potential of essential oils and extracts } \\
\text { from the Verbenaceae and Labiatae } \\
\text { families, with activity against important } \\
\text { dermatological fungi such as F. oxysporum, } \\
\text { and dermatophytes as T. rubrum and } \\
\text { T. mentagrophytes. }\end{array}$ \\
\hline 电 & 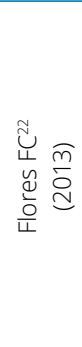 & $\begin{array}{l}\text { Antifungal activity } \\
\text { of suspensions } \\
\text { of nanocapsules } \\
\text { containing } \\
\text { Melaleuca oil } \\
\text { on the growth } \\
\text { of Trichophyton } \\
\text { rubrum. }\end{array}$ & $\begin{array}{l}\text { Rio Grande do } \\
\text { Sul, Brazil. }\end{array}$ & $\begin{array}{l}\text { Cohort study; } \\
\text { LE IV }\end{array}$ & $\begin{array}{l}\text { To evaluate, for } \\
\text { the first time, the } \\
\text { antifungal efficacy } \\
\text { of nanocapsules } \\
\text { and nanoemulsions } \\
\text { containing essential } \\
\text { oil of Melaleuca } \\
\text { alternifolia in an } \\
\text { onychomycosis } \\
\text { model. }\end{array}$ & $\begin{array}{l}\text { Melaleuca } \\
\text { alternifolia }\end{array}$ & $\begin{array}{l}\text { Nanocapsules containing M. alternifolia } \\
\text { essential oil were the most effective } \\
\text { in reducing the growth of T. rubrum. } \\
\text { Another advantage of this system was } \\
\text { the prevention of nail infection caused } \\
\text { by T. rubrum in an in vitro onychomycosis } \\
\text { model, demonstrating the potential of } \\
\text { nanoencapsulation in the treatment of } \\
\text { superficial mycoses. }\end{array}$ \\
\hline
\end{tabular}


Table 2. Continuation...

\begin{tabular}{|c|c|c|c|c|c|c|c|}
\hline ํํㅁ & 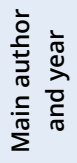 & Study title & $\begin{array}{l}\text { Study } \\
\text { location }\end{array}$ & $\begin{array}{c}\text { Type of study } \\
\text { and LE }\end{array}$ & Objective & $\begin{array}{l}\text { Intervention } \\
\text { (Essential oil) }\end{array}$ & Main results \\
\hline$\frac{\circ}{<}$ & 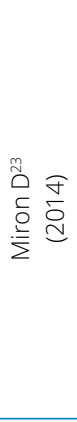 & $\begin{array}{l}\text { Antifungal activity } \\
\text { and mechanism } \\
\text { of action of } \\
\text { monoterpenes } \\
\text { against } \\
\text { dermatophytes } \\
\text { and yeasts. }\end{array}$ & $\begin{array}{l}\text { Rio Grande do } \\
\text { Sul, Brazil. }\end{array}$ & $\begin{array}{l}\text { Cohort study; } \\
\text { LE IV }\end{array}$ & $\begin{array}{l}\text { Establish the } \\
\text { antifungal activity of } \\
\text { some monoterpenes } \\
\text { found in volatile oils } \\
\text { (GOL, NOL, GAL, } \\
\text { NAL and CIT) and } \\
\text { investigate possible } \\
\text { mechanisms of action } \\
\text { for these substances. }\end{array}$ & Monoterpenos & $\begin{array}{l}\text { The antifungal activity of geraniol, nerol, } \\
\text { citral, neral and geranial (monoterpenes) } \\
\text { and terbinafine and anidulafungin (control } \\
\text { drugs) against seven opportunistic } \\
\text { pathogenic yeasts and four species } \\
\text { of dermatophytes was evaluated by } \\
\text { microdilution tests. Monoterpenes were } \\
\text { more active against dermatophytes } \\
\text { than against yeasts with } 34.5 \text { and } \\
100.4 \mu \text { g. } \mathrm{ml}^{-1} \mathrm{GMCl} \text { Ergosterol relating its } \\
\text { mechanism of action to the destabilization } \\
\text { of the cell membrane. }\end{array}$ \\
\hline $\bar{\tau}$ & 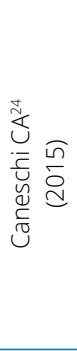 & $\begin{array}{l}\text { In vitro antifungal } \\
\text { activity of } \\
\text { Baccharis trimera } \\
\text { less (DC) essential } \\
\text { oil against } \\
\text { dermatophytes. }\end{array}$ & $\begin{array}{l}\text { Rio de Janeiro, } \\
\text { Brazil. }\end{array}$ & $\begin{array}{l}\text { Cohort study; } \\
\text { LE IV }\end{array}$ & $\begin{array}{l}\text { Identify the main } \\
\text { components of } \\
\text { the essential oil of } \\
\text { Baccharis trimera } \\
\text { Less and investigate } \\
\text { its antifungal } \\
\text { activity in vitro } \\
\text { against seven fungal } \\
\text { strains that cause } \\
\text { onychomycosis. }\end{array}$ & $\begin{array}{l}\text { Baccharis } \\
\text { trimera less }\end{array}$ & $\begin{array}{l}\text { The essential oil has antifungal activity } \\
\text { against filamentous fungi and can be used } \\
\text { as an alternative for the treatment of } \\
\text { onychomycosis. The essential oil of } \\
\text { B. trimera has an antifungal effect } \\
\text { against two of the three genera of } \\
\text { filamentous fungi. }\end{array}$ \\
\hline$\frac{N}{<}$ & 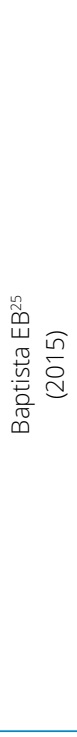 & $\begin{array}{l}\text { Chemical } \\
\text { composition and } \\
\text { antifungal activity } \\
\text { of Eucalyptus } \\
\text { smithii essential } \\
\text { oil against } \\
\text { dermatophytes. }\end{array}$ & $\begin{array}{l}\text { Minas Gerais, } \\
\text { Brazil. }\end{array}$ & $\begin{array}{l}\text { Cohort study; } \\
\text { LE IV }\end{array}$ & $\begin{array}{l}\text { Investigate the } \\
\text { antifungal activity of } \\
\text { the essential oil of } \\
\text { Eucalyptus smithii R.T. } \\
\text { Baker against the } \\
\text { main filamentous } \\
\text { fungi that cause } \\
\text { dermatophytosis, } \\
\text { such as Microsporum } \\
\text { canis, Microsporum } \\
\text { gypseum, Trichophyton } \\
\text { mentagrophytes } \\
\text { and Trichophyton } \\
\text { rubrum in vitro, } \\
\text { and determine the } \\
\text { micromorphological } \\
\text { changes resulting } \\
\text { from these fungi, } \\
\text { using scanning } \\
\text { electron microscopy } \\
\text { (SEM). }\end{array}$ & $\begin{array}{l}\text { Eucalyptus } \\
\text { smithii }\end{array}$ & $\begin{array}{l}\text { The potential of Eucalyptus smithii essential } \\
\text { oil was identified as a natural therapeutic } \\
\text { agent for the treatment of dermatophytosis. }\end{array}$ \\
\hline$\frac{m}{\varepsilon}$ & 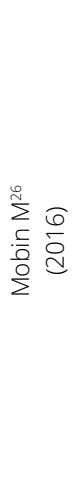 & $\begin{array}{l}\text { MDGC-MS } \\
\text { analysis of } \\
\text { essential oils } \\
\text { from Protium } \\
\text { heptaphyllum } \\
\text { (Aubl.) and its } \\
\text { antifungal activity } \\
\text { against species of } \\
\text { Candida. }\end{array}$ & $\begin{array}{l}\text { Teresina, } \\
\text { Brazil. }\end{array}$ & $\begin{array}{l}\text { Cohort study; } \\
\text { LE IV }\end{array}$ & $\begin{array}{l}\text { Analyze the chemical } \\
\text { composition of resin } \\
\text { essential oil } \\
\text { P. heptaphyllum } \\
\text { (OEPh) at different } \\
\text { times of extraction } \\
\text { and to evaluate its } \\
\text { antifungal activity } \\
\text { against species of } \\
\text { Candida isolated } \\
\text { from horticulturists } \\
\text { with onychomycosis, } \\
\text { by disk-diffusion } \\
\text { method. }\end{array}$ & $\begin{array}{l}\text { Protium } \\
\text { heptaphyllum }\end{array}$ & $\begin{array}{l}\text { There was considerable antifungal activity } \\
\text { of the protium oil resin, inhibiting species } \\
\text { of Candida, by the disk diffusion method, } \\
\text { with halo diameter ( } X>14 \mathrm{~mm}) \text {, which cause } \\
\text { a wide spectrum of superficial invasive } \\
\text { infections and nail infections. }\end{array}$ \\
\hline
\end{tabular}

$\mathrm{LE}=$ Level of Evidence; $T$ TO = Tea Tree Oil; MIC = Minimum Inhibitory Concentration; GOL = Geraniol; NOL = Nerol; GAL = Geranial; NAL = Neral; CIT = Citral; GMIC =Geometric mean of the minimum inhibitory concentration; MDGC/EM = Multidimensional Gas Chromatography associated with mass spectrometry. 


\section{DISCUSSION}

The articles included in this review bring studies that seek to prove the antifungal efficacy of essential oils ${ }^{14,18}$ as well as its composition and mechanisms of action ${ }^{15-17,19-25}$. Thus, including analyzes of the association of substances, composition, comparison and different formulations against the main etiological agents of onychomycosis.

The oldest article in the present study and with the highest LE, it is a double-blind, multicenter, randomized and controlled clinical trial, which addresses the efficacy and tolerability of topical application of $1 \%$ clotrimazole solution (CL) compared to pure oil of Melaleuca alternifolia 100\% (TT) for the treatment of onychomycosis. Finding similar results with the two therapies at the end of the 6 months of the research, with curing of the culture $(\mathrm{CL}=11 \%, \mathrm{TT}=18 \%)$ and partial or total resolution $(\mathrm{CL}=61 \%, \mathrm{TT}=60 \%)$ according to evaluation clinic ${ }^{14}$.

Melaleuca alternifolia oil in different concentrations, proposed by the clinical trial, also reversibly inhibited the formation of germ tubes (FGT) in C. albicans in the highest concentrations of oil (0.25\%). However, at lower concentrations $(0.125 \%)$, FGT was specifically inhibited while growth continued through sprouting. These findings may be due to the effects on cell membranes and associated functions, including inhibition of breathing ${ }^{15}$.

In other studies, a cohort and a randomized controlled clinic, associations of components to the essential oil of Melaleuca alternifolia were presented, seeking knowledge about a supposed increased fungicidal effect. ${ }^{17-18,20}$.In one study, two essential oils, Melaleuca alternifolia and Lavandula angustifolia, were combined to inhibit Trichophyton rubrum, a dermatophyte fungal agent that colonizes the surface of human skin and is the main cause of "athlete's foot" and onychomycosis. On day 7, a proportion of $30 \% \mathrm{v} / \mathrm{v}$ lavender or $20 \% \mathrm{v} / \mathrm{v}$ of Melaleuca oil was used, resulting in $100 \%$ inhibition. On day 14 , the minimum dilution to maintain $100 \%$ inhibition was $40 \% \mathrm{v} / \mathrm{v}$ lavender or $30 \% \mathrm{v} / \mathrm{v}$ Melaleuca oil. In the analysis of synergy of oils, the minimum dilution of mixtures of essential oils that give $100 \%$ inhibition was $10 \% \mathrm{v} / \mathrm{v}$ lavender with $20 \% \mathrm{v} / \mathrm{v}$ Melaleuca oil or $20 \% \mathrm{v} / \mathrm{v}$ lavender with $10 \% \mathrm{v} / \mathrm{v}$ Melaleuca oil. On day 14 , the cultures that had been exposed to these mixtures also maintained $100 \%$ inhibition. Thus, confirming that the synergistic action occurs between these two essential oils commonly used in effecting antifungal activity ${ }^{17}$.

Another association tested in a clinical study was topical therapy with 5\% Melaleuca alternifolia oil and 2\% butenafine hydrochloride. This cream, in conjunction with debridement with a nail clipper, was considered safe, tolerable and significantly more effective than placebo (Melaleuca oil only) for curing toe nail onychomycosis. Result evidenced after verifying $80 \%$ of cure in the group that used the association for 8 weeks, against no case of cure in the group that used the placebo. Raising the hypothesis that the time was not enough for healing in the group that used only Melaleuca oil, since this has proven efficacy by several studies ${ }^{18}$.

In the evaluation of the antifungal effect, in a cohort study, against Candida albicans of Melaleuca oil associated with chitosan, it was found that it did not significantly improve the activity of the oil, a finding that can be explained due to the longer time that the inhibitory concentrations of chitosan need to show your activity. Individually, Melaleuca oil inhibited C. albicans at $0.5 \% \mathrm{v} / \mathrm{v}$ and was able to kill yeast cells in 120 minutes at $1 \%$ and in 300 minutes between 0.5 and $0.25 \%$. Regarding chitosan, $0.5 \mathrm{mg} / \mathrm{mL}$ was needed to inhibit the growth of Candida in a liquid environment, while $0.5-2 \mathrm{mg} / \mathrm{mL}$ of chitosan was required 24 hours to kill them in the death kinetics test. bacterial (time-kill) ${ }^{20}$.

The therapeutic effect of Foeniculum vulgare oil was investigated through a cohort study that considered it fungicidal at concentrations of $0.2 ; 0.4$ and $0.5 \mu \mathrm{l} / \mathrm{ml}$, at 50,60 and 80 minutes, against Trichophyton rubrum, T. mentagrophytes and Scytalidium dimidiatum, respectively. Pure oil (100\%) killed fungi in just 5 seconds. In addition to the agents mentioned above, the oil was also effective against Candida albicans, Epidermophyton floccosum, $M$. canis, among others, in the concentration range of 0.5-1.0 $\mu 1 / \mathrm{ml}$. Among its characteristics, we can mention the long shelf life, thermostability and absence of adverse effects ${ }^{16}$.

The effectiveness of Vick's Vaporub and the minimum concentration for $100 \%$ inhibition on the pathogens responsible for onychomycosis were determined by means of an in vitro cohort study. Inhibition data revealed 
that camphor, menthol, thymol and Eucalyptus citriodora oil were the most effective components against the test organisms (Tricophyton rubrum, Trichophyton mentagrophytes, Microsporum canis, Epidermophyton floccosum and Epidermophyton stockdale). The minimum concentration for 100\% inhibition for mixtures of these four components in various solvents revealed that formulations with concentrations of $5 \mathrm{mg} / \mathrm{mL}$ of each have the potential to be effective in the control of onychomycosis ${ }^{19}$.

The antifungal activity of 14 essential oils (Aloysia triphylla, Lippia alba N.E.Brown, Lippia micrômera Schauer, Lippia origanoides Kunth, Lantana fucata Lindl) and 1 extract (Lantana fucata Lindl) belonging to the Verbenaceae families, and 3 oils (Minthostachys mollis Griseb, Origanum vulgare) and 2 extracts (Lepechinia conferta and Salvia melaleuca subsp. Melaleuca) belonging to the Labiatae family was strong between $70 \%$ and $80 \%$ of the samples evaluated against dermatophytes (Trichophyton rubrum and T. mentagrophytesde) and $20 \%$ against $F$. oxysporum.It should be noted that the same plant had its oil extracted in different planting regions and times of the year, allowing for more analysis options as detailed in the study. The lowest values of Minimum Inhibitory Concentration (MIC) were obtained with the citral chemotype of Lippia alba oil at concentrations of 31.25 and $125 \mu \mathrm{g} / \mathrm{mL}$ in T. rubrum and T. mentagrophytes, respectively, but not in F. oxysporum ${ }^{21}$.

In addition, Minthostachys mollis Griseb oil showed strong activity against all evaluated fungi. The essential oils with the highest selectivity index values were Aloysia triphylla and L. alba oil in dermatophytes. The main component of the most active oils of L. alba was characterized by carvona and citral. For L. origanoides, carvacrol and thymol were found as the main component. Pulegone and cis-piperitone epoxide were the main constituents of Minthostachys mollis oils. The presence of these major components in essential oils may be responsible for antifungal activity. These findings are very important because they confirm the potential of essential oils as a source of new anti-dermatophytes 21 .

The antifungal activity of nanocapsule suspensions containing Melaleuca oil was evaluated, by a cohort study, on the growth of Trichophyton rubrum, one of the main causes of onychomycosis. The results showed a greater efficiency in the use of nanocapsules compared to nanoemulsion and conventional emulsion. Nanocapsules, unlike nanoemulsions, are formed by a polymeric wall arranged around the oil core, which protects the immediate delivery of the oil, providing, by chance, a gradual release of oil and maintaining its concentrations for a longer time ${ }^{22}$. A previous study by the same author also shows that the inclusion of Melaleuca oil in nanocapsules showed greater protection against volatilization ${ }^{27}$.

In a cohort study carried out in Brazil, positive results of monoterpenes, present in essential oils, were presented in the "Affinity Test with Ergosterol" and the other reports on the subject strongly suggest that the mechanism of action of this class of drugs is related to the ergosterol link and the subsequent destabilization of fungal cell membranes ${ }^{23}$.

The essential oil of $B$. trimera (Minimum Fungal Concentration/MFC $=0.06 \mu \mathrm{g} \mathrm{mL}^{-1}$ ) was more potent

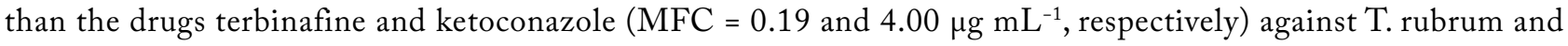

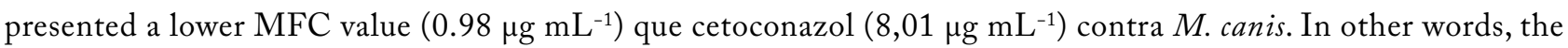
antifungal activity of essential oil against two strains of fungi, T. rubrum e $M$. canis, was higher when compared to ketoconazole ${ }^{24}$. These data are in agreement with other studies that stated that plants of the genus Baccharis L. are used in Argentina and other South American countries for the treatment of fungal diseases ${ }^{28}$.

The 1,8-cineol compound is the predominant component (72.2\%) of Eucalyptus smithii essential oil. The MIC values of the oil ranged from $62.5 \mu \mathrm{g} \cdot \mathrm{mL}^{-1}$ to $>1.000 \mu \mathrm{g} \cdot \mathrm{mL}^{-1}$, and the MFC values of the oil ranged from $125 \mu \mathrm{g} \cdot \mathrm{mL}^{-1}$ to $>1.000 \mu \mathrm{g} \cdot \mathrm{mL}^{-1}$. The analysis by electron microscopic scanning showed physical and morphological damage as changes in the fungi exposed to this oil, demonstrating the potential of Eucalyptus smithii essential oil as a natural therapeutic agent for the treatment of dermatophytosis ${ }^{25}$.

Against Candida species isolated from horticulturists with onychomycosis, by the method of disc-diffusion, the essential oil of the Protium heptaphyllum resin has antifungal activity. Important result being one of the main 
species causing onychomycosis. Demonstrating inhibition, even, with C. krusei, naturally resistant to the drug fluconazole, a similar situation occurred with the strain of C. parapsilosis ${ }^{26}$.

The results of the studies suggest evidence that essential oils are effective and beneficial in the treatment for onychomycosis. Therefore, health professionals involved in the care of patients with onychomycosis must keep up to date on such alternatives for the treatment of onychomycosis and, consequently, of improving the quality of life of these patients.

As a limitation for the elaboration of this integrative review, the presence of studies with low scientific evidence stands out, as well as few clinical studies on the topic discussed.

\section{CONCLUSION}

In view of the analyzed articles, it can be said that studies on essential oils present promising data, but these are mostly from preclinical studies, even though in the two included clinical trials the data have pointed to therapeutic efficacy.

The clinical studies presented show that essential oils, when compared to other therapies, proved to be as effective as conventional therapies, such as clotrimazole, terbinafine and ketoconazole.

However, most of the studies identified have a low level of evidence because they are pre-clinical studies, thus showing the need for the production of studies with experimental design, which can safely base the application in clinical practice, also aiming at contribution in the care of patients affected by this pathology.

\section{AUTHORS' CONTRIBUTION}

Conceptualization: Ribeiro TB, Bezerra SMG, Lira JAC e Oliveira RA; Methodology: Ribeiro TB, Lira JAC, Machado RS, Bezerra SMG e Oliveira RA; Research: Ribeiro TB, Bezerra SMG, Lira JAC e Oliveira RA;Writing - First version: Ribeiro TB, Bezerra SMG, Lira JAC, Oliveira RA e Machado RS; Writing - Review \& Editing: Ribeiro TB; Lira JAC; Bezerra SMG; Oliveira RA; Machado RS e Nogueira LT; Supervision: Ribeiro TB.

\section{DATA STATEMENT AVAILABILITY}

Not applicable

\section{REFERENCES}

1. Vlahovic TC. Onychomycosis: Evaluation, Treatment Options, Managing Recurrence, and Patient Outcomes. Clin Podiatr Med Surg. 2016;33(3):305-18. https://doi.org/10.1016/j.cpm.2016.02.001

2. Elewski BE, Tosti A. Risk Factors and Comorbidities for Onychomycosis: Implications for Treatment with Topical Therapy. J Clin Aesthet Dermatol. 2015;8(11):38-42. Available at: https://www.ncbi.nlm.nih.gov/pmc/articles/PMC4689496/pdf/ jcad_8_11_38.pdf

3. Maquiné GA. Estudo descritivo dos casos de onicomicoses atendidos em um centro de referência em dermatologia na cidade de Manaus [dissertação]. Manaus (AM): Mestrado em doenças tropicais e infecciosas, Universidade do Estado do Amazonas; 2017.

4. Maranhão FCA, Oliveira-Júnior JB, Araújo, MAS, Silva DMW. Mycoses in northeastern Brazil: epidemiology and prevalence of fungal species in 8 years of retrospective analysis in Alagoas. Braz J Microbiol. 2019;50(4):969-78. https://doi.org/10.1007/ s42770-019-00096-0

5. Rato M, Costin A, Furtado C, Sousa C, Toscano C, Veríssimo C et al. Epidemiologia das Infeções Fúngicas Superficiais em Portugal: Revisão de 3 Anos (2014-2016). Revista SPDV 2018;76(3):269-78. https://doi.org/10.29021/spdv.76.3.910

6. Achterman RR, White TC. A foot in the door for dermatophyte research. PLoS Pathog. 2012;8(3):e1002564. https://doi. org/10.1371/journal.ppat.1002564 
7. Morales-Cardona CA, Valbuena-Mesa MC, Alvarado Z, Solorzano-Amador A. Non-dermatophyte mould onychomycosis: a clinical and epidemiological study at a dermatology referral centre in Bogota, Colombia. Mycosis. 2014;57(5):284-93. http://doi.org/10.1111/myc.12157

8. Andrei P, Comune AP. Aromaterapia e suas aplicações. Centro Universitário S. Camilo 2005;11(4):57-68. Available at: http://www.saocamilo-sp.br/pdf/cadernos/36/07_aromaterapia.pdf

9. Cóbar MLP. Aromaterapia [dissertação]. Guatemala. Dissertação: Facultad de Humanidades, Universidad de San Carlos de Guatemala; 2005.

10. Bizzo HR, Hovell AMC, Rezende CM. Óleos essenciais no Brasil: aspectos gerais, desenvolvimento e perspectivas. Quim Nova 2009;32(3):588-94. https://doi.org/10.1590/S0100-40422009000300005

11. Serafini LA, Santos ACA, Touguinha LA, Agostini G, Dalfovo V. Extrações e aplicações de óleos essenciais de plantas aromáticas e medicinais. $1^{\text {a }}$ ed. Caxias do Sul: Educs; 2002.

12. Mendes KDS, Silveira RCCP, Galvão CM. Revisão integrativa: método de pesquisa para a incorporação de evidências na saúde e na enfermagem. Texto Contexto Enferm. 2008;17(4):758-64. Available at: http://www.scielo.br/pdf/tce/v17n4/18. pdf

13. Melnyk BM, Fineout-Overholt E. Evidence-based practice in nursing \& healthcare: a guide to best practice. $3^{\mathrm{a}}$ ed. Philadelphia: Lippincott Williams \& Wilkins; 2014

14. Buck DS, Nidorf DM, Addino JG. Comparison of two topical preparations for the treatment of onychomycosis: Melaleuca alternifolia (tea tree) oil and clotrimazole. J Fam Pract. 1994;38(6):601-5. Available at: https://pubmed.ncbi.nlm.nih. gov/8195735/

15. Hammer KA, Carson CF, Riley TV. In vitro activity of Melaleuca alternifolia (tea tree) oil against dermatophytes and other filamentous fungi. J Antimicrobial Chemother. 2002;50(2):195-9. https://doi.org/10.1093/jac/dkf112

16. Patra M, Shahi SK, Midgely G, Dikshit A. Utilization of essential oil as natural antifungal against nail-infective fungi. Flavour Fragr J. 2002;17(2):91-4. https://doi.org/10.1002/ffj.1049

17. Cassella S, Cassella JP, Smith I. Synergistic antifugal activity of tea tree (Melaleuca Alternifolia) and lavender (Lavandula angustifolia) essential oils against dermatophyte intection. Int J Aromath. 2002; 12(1):2-15. https://doi.org/10.1054/ ijar.2001.0127

18. Syed TA, Qureshi ZA, Ali SM, Ahmad S, Ahmad SA. Treatment of toenail onychomycosis with $2 \%$ butenafine and $5 \%$ Melaleuca alternifólia (tea tree) oil in cream. Trop Med Int Health. 1999;4(4):284-7. https://doi.org/10.1046/j.13653156.1999.00396.x

19. Ramsewak RS, Nair MG, Stommel M, Selanders L. In vitro antagonistic activity of monoterpenes and their mixtures against 'toe nail fungus' pathogens. Phytother Res. 2003;17(4):376-9. https://doi.org/10.1002/ptr.1164

20. Juliano C, Demurtas C, Piu L. In vitro study on the anticandidal activity of Melaleuca alternifolia (tea tree) essential oil combined with chitosan. Flavour Fragr J. 2008;23(4):227-31. https://doi.org/10.1002/ffj.1871

21. Castaño VT, Linares VR, Betancur L, Durán DC, Stashenko E, Mesa AC. Antifungal activity of Verbenaceae and Labiatae families essential oils. PharmacologyOnline. 2012; 1(special issue):133-45. Available at: https://www.researchgate.net/ profile/Liliana-Betancur/publication/256475420_Antifungal_activity_of_Verbenaceae_and_Labiatae_families_essential_ oils/links/00b49523662d20ec55000000/Antifungal-activity-of-Verbenaceae-and-Labiatae-families-essential-oils.pdf

22. Flores FC, Lima JA, Ribeiro RF, Alves SH, Rolim CMB, Beck RCR et al. Antifungal Activity of Nanocapsule Suspensions Containing Tea Tree Oil on the Growth of Trichophyton rubrum. Mycopathologia. 2013;175(3-4):281-6. https://doi. org/10.1007/s11046-013-9622-7

23. Miron D, Battisti F, Silva FK, Lana AD, Pippi B, Casanova B et al. Antifungal activity and mechanism of action of monoterpenes against dermatophytes and yeasts. Rev bras farmacogn. 2014;24(6):660-7. https://doi.org/10.1016/j.bjp.2014.10.014

24. Caneschi CA, Martins FJ, Larrudé DG, Romani EC, Brandão MAF, Raposo NRB. In vitro Antifungal Activity of Baccharis trimera Less (DC) Essential Oil against Dermatophytes. Trop J Pharm Res. 2015;14(11):2083-9. https://doi.org/10.4314/ tjpr.v14i11.19

25. Baptista EB, Zimmermann-Franco DC, Lataliza AAB, Raposo NRB. Chemical composition and antifungal activity of essential oil from Eucalyptus smithii against dermatophytes. Rev Soc Bras Med Trop. 2015;48(6):746-52. https://doi. org/10.1590/0037-8682-0188-2015

26. Mobin M, Lima SG, Almeida LTG, Takahashi JP, Teles JB, Szeszs MW et al. MDGC-MS analysis of essential oils from Protium heptaphyllum (Aubl.) and their antifungal activity against Candida specie. Rev bras plantas med. 2016;18(2):531-8. https:// doi.org/10.1590/1983-084X/15_110 
27. Flores FC. Sistemas nanoestruturados contendo óleo essencial de Melaleuca alternifólia: desenvolvimento de formulações e atividade biológica [dissertação]. Santa Maria (RS): Mestrado do Programa de Pós-graduação em ciências farmacêuticas, Universidade Federal de Santa Maria; 2011.

28. Rodriguez MV, Sortino MA, Ivancovich JJ, Pellegrino JM, Favier LS, Raimondi MP et al. Detection of synergistic combinations of Baccharis extracts with Terbinafine against Trichophyton rubrum with high throughput screening synergy assay (HTSS) followed by 3D graphs. Behavior of some of their componentes. Phytomedicine. 2013;20(13):1230-9. https://doi. org/10.1016/j.phymed.2013.06.015 